\title{
Philosophiques
}

\section{Illustration : J. Cirincione, B. D'Amato et M. Ferraro, The Imperial Message : Grid with Characters, 1993-1994}

Volume 23, numéro 1, printemps 1996

Critères esthétiques et métamorphoses du beau

URI : https://id.erudit.org/iderudit/027361ar

DOI : https://doi.org/10.7202/027361ar

Aller au sommaire du numéro

Éditeur(s)

Société de philosophie du Québec

ISSN

0316-2923 (imprimé)

1492-1391 (numérique)

Découvrir la revue

Citer ce document

(1996). Illustration : J. Cirincione, B. D'Amato et M. Ferraro, The Imperial Message : Grid with Characters, 1993-1994. Philosophiques, 23(1), 14-14.

https://doi.org/10.7202/027361ar d'utilisation que vous pouvez consulter en ligne. 


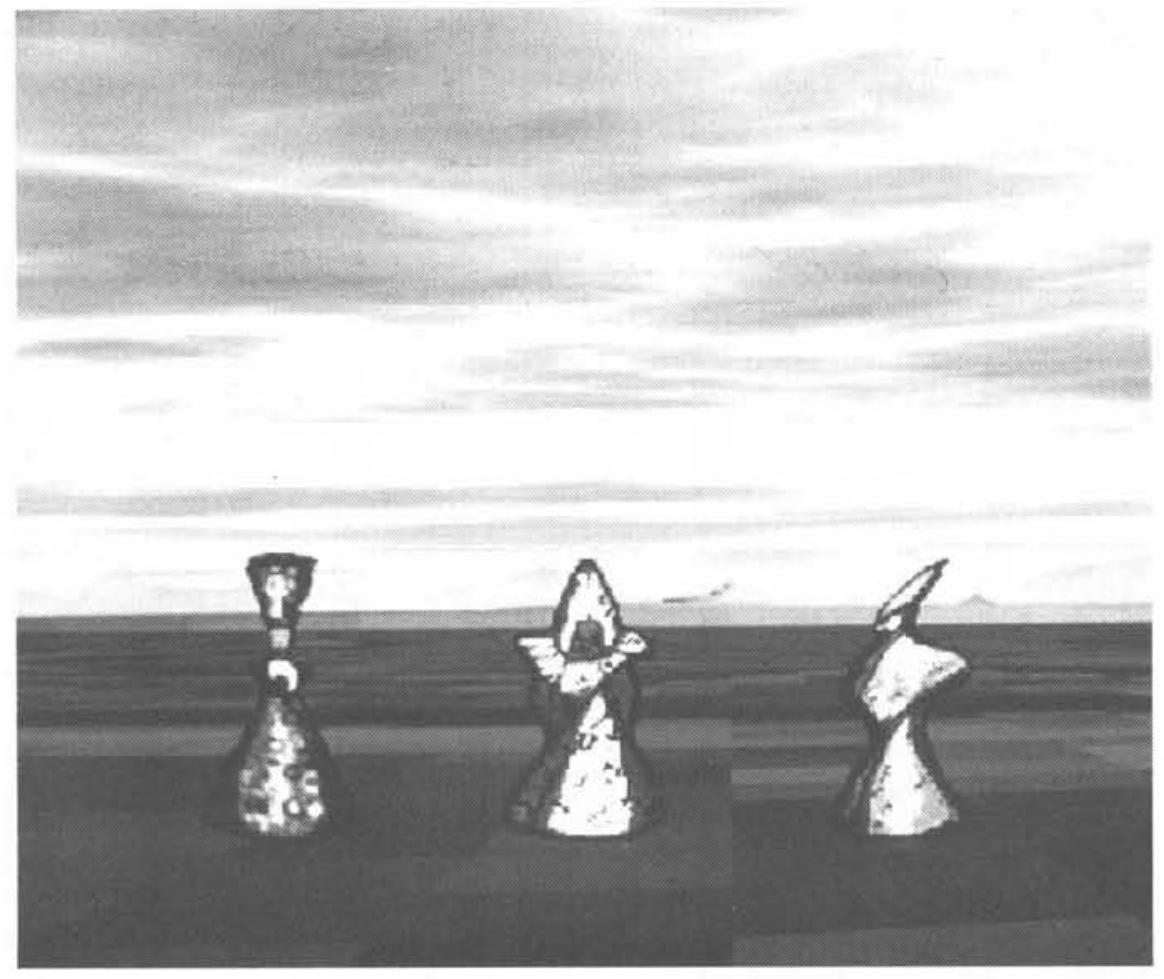

Janine Cirincione, Brian D'Amato et Michael Ferraro The Imperial Message : Grid with Characters, 1993-1994

Softworlds. Inc. (USA).

Réalité virtuelle. Illustration de Esthétique des arts médiatiques (Louise Poissant, UQAM, 1995) 